Published by LPMP Imperium

Journal homepage: https:/ / ejournal.imperiuminstitute.org/index.php/ AKURASI

\title{
Determinan Kecenderungan Kecurangan Akuntansi
}

Adhilla Aninta Putri, Swarmilah Hariani*

Fakultas Ekonomi dan Bisnis, Universitas Mercu Buana

Jakarta, Indonesia

\section{Research Paper}

Accounting \&Auditing

\begin{abstract}
This research aims to prove the influence of the effectiveness of internal control, compliance with accounting rules, compensation, and asymmetry information against the tendency of accounting fraud. The object of this research was conducted on local government employees in the Pekanbaru City Regional Work Unit (SKPD) total 43 SKPD. This research was conducted against the 108 respondents using primary data through a questionnaire that was distributed directly to the respondents. The results of this study indicate that the effectiveness of internal control, compliance with accounting rules, compensation significant negative effect on the tendency of accounting fraud, and asymmetry of information significant positive effect on the tendency of accounting fraud. Test results revealed that the simultaneous effectiveness of internal control, compliance with accounting rules, compensation, and asymmetry information collectively influence the tendency of accounting fraud.
\end{abstract}

\section{Keywords:}

effectiveness of internal control, compliance with accounting rules, compensation, asymmetry information, the tendency of accounting fraud

\section{Corresponding Author:}

Swarmilah Hariani, Fakultas Ekonomi dan Bisnis, Universitas Mercu Buana, Jakarta, Indonesia

Email: swarmilah@mercubuana.ac.id

(C) The Author(s) 2021

DOI: https:/ / doi.org/ 10.36407/ akurasi.v3i1.225
Received: 06 Aug 2020

Revised: 05022021

Accepted: 15022021

Online: 20 Feb 2021

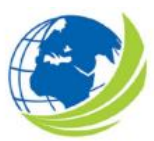

Akurasi: Jurnal Riset Akuntansi dan Keuangan, Vol 3, No.1, 2021, pp. $17-28$

eISSN 2685-2888

\section{(C)}

CC BY: This license allows reusers to distribute, remix, adapt, and build upon the material in any medium or format, so long as attribution is given to the creator. The license allows for commercial use. 


\section{PENDAHULUAN}

Semakin majunya perekonomian Indonesia tidak lepas dari peran industri perbankan dalam Laporan keuangan yang merupakan subyek audit. Salah saji material dalam laporan keuangan akan menyesatkan stakeholder atau pengguna laporan keuangan karena informasi yang ada dalam laporan keuangan tersebut tidak mencerminkan kondisi organisasi yang sebenarnya.Menurut Wilopo (2006), pada umumnya kecurangan akuntansi berkaitan dengan korupsi. Dalam korupsi, tindakan yang lazimdilakukan adalah memanipulasi, pencatatan, penghilangan dokumen, dan mark-up yang merugikan keuangan atauperekonomian negara. Kecenderungan menunjukan adanya indikasi untuk melakukan tindakan yang mengarah adanya kecurangan atau penipuan. Kecenderungan kecurangan akuntansi dapat dikatakan sebagai tendensi korupsi dalam definisi dan terminologi karena keterlibatan beberapa unsur yang terdiridari fakta-fakta menyesatkan, pelanggaran aturan atau penyalahgunaan kepercayaan, dan omisi fakta kritis (Adelin, 2013).

Di Indonesia baik dalam suatu instansi pemerintah maupun swasta tindak kecurangan akuntansi sudah menjadi kebiasaan dari tahun ketahun. Indonesia termasuk negara yang memiliki tingkat korupsi yang tinggi di dunia. Berdasarkan pengukuran Corruption Perception Index (CPI) untuktahun 2017, tingkat korupsi Indonesia menempati posisi ke-96 dari 180 negara yang diukur (Transparancy Internasional, 2018).Menurut data yang dirilis Indonesia Curruption Watch (ICW) semester I tahun 2017 dimana Riau masuk dalam lima besar dengan jumlah kasus korupsi terbesar. Dimana Riau sendiri semester pertama tahun 2017 jumlah kasus korupsi ada 19 kasus dengan kerugian mencapai Rp 211 Miliar (pekanbaru.tribunnews.com, 2017).

Kasus kecurangan ini bisa disebabkan antara lain dikarenakan pengendalian internal yang rendah. Faktanya fenomena yang terjadi yaitu selama semester 1 Tahun 2013, BPK RI menemukan sebanyak13.969 kasus kelemahan sistem pengendalian intern (SPI) dan ketidakpatuhan terhadap perundang-undangan senilai Rp 56,98 triliun. Dari 13.969 kasus tersebut sebanyak 4.589 kasus senilai Rp 10,74 triliun merupakan temuan ketidakpatuhan yang mengakibatkan kerugian, potensi kerugian, dan kekurangan penerimaan (BPK, 2013). Faktor lain yang menyebabkan maraknya tindak kecurangan akuntansi di Indonesia adalah ketaatan aturan akuntansi. Suatu instansi atau lembaga akan melakukan tindakan kecurangan karena mereka tidak berpedoman pada aturan akuntansi yang berlaku. Fenomena ini terlihat pada kasus yang ditemukan oleh Badan Pemeriksa Keuangan (BPK) yang menyebutkan bahwa hasil pemeriksaan terhadap 662 objek pemeriksaan terdapat sebanyak 3.452 kasus senilai Rp 9,24 triliun yang berdampak finansial yang merupakan temuan ketidakpatuhan terhadap ketentuan perundang-undangan yang mengakibatkan kerugian Negara, potensi kerugian Negara dan kekurangan penerimaan (BPK, 2014).

Selain faktor-faktor yang telah diuraikan sebelumnya, kesesuaian kompensasi juga merupakan faktor yang mempengaruhi terjadinya kecurangan akuntansi. Fenomena tersebut dikuatkan dengan pernyataan Direktur Gratifikasi Komisi Pemberantas Korupsi (KPK) Giri Supradiono yang menjelaskan bahwa dari berbagai kasus yang terjadi, gratifikasi yang dilakukan para PNS disebabkan pendapatan dari gaji dan tunjangan yang diterimanya rendah. Akibatnya, para PNS berusaha mencari tambahan dengan berbagai cara, termasuk menerima gratifikasi (Shintadevi, 2015).

Faktor lain yang mempengaruhi terjadinya kecenderungan kecurangan akuntansi yaitu asimetri informasi. Kusumastuti (2012) dalam Azmi (2017) mencatat bahwa tindakan yang dilakukan oleh manajemen dipengaruhi oleh situasi asimetri informasi. Asimetri informasi 
adalah situasi ketika terjadi ketidakselarasan informasi antara pihak yang menyediakan informasi dengan pihak yang membutuhkan informasi. Asimetri informasi disebabkan oleh permasalahan keagenan yang terjadi bila prinsipal merasa kesulitan untuk menelusuri apa yang sebenarnya dilakukan oleh agen. Penelitian ini bertujuan mengahui pengaruh efektivitas pengendalian internal, ketaatan aturan akuntansi, dan komitmen organisasi terhadap kecenderungan kecurangan (fraud) akuntansi.

\section{KAJIAN PUSTAKA}

Teori Stewardship adalah teori yang menggambarkan situasi dimana para manajer tidaklah termotivasi oleh tujuan-tujuan individu tetapi lebih ditujukan pada sasaran hasil utama mereka untuk kepentingan organisasi, sehingga teori ini mempunyai dasar psikologi dan sosiologi yang telah dirancang dimana para eksekutif sebagai steward termotivasi untuk bertindak sesuai keinginan prinsipal, selain itu perilaku steward tidak akan meninggalkan organisasinya sebab steward berusaha mencapai sasaran organisasinya. Teori ini didesain bagi para peneliti untuk menguji situasi dimana para eksekutif dalam perusahaan sebagai pelayan dapat termotivasi untuk bertindak dengan cara terbaik pada principalnya (Donaldson dan Davis, 1989, 1991).

Teori ini digunakan karena teori ini memandang bahwa kepercayaan atas manajemen dapat terjadi jika manajemen bertindak sesuai dengan kepentingan-kepentingan yang muncul, yaitu kepentingan publik pada umumnya dan kepentingan shareholders pada khususnya. Teori ini menjelaskan bahwa kinerja perusahaan dapat meningkat karena adanya sifat amanah dan setia manajer perusahaan terhadap komitmen dalam perusahaan (Kurniawan, 2013). Teori Stewardship menjelaskan bahwa kepentingan bersama dijadikan dasar dari tindakan seorang manajer. Jika terdapat perbedaan kepentingan antara principal dan steward, maka stewardakan berusaha bekerjasama karena bertindak sesuai dengan tindakan principal dan demi kepentingan bersama dapat menjadi pertimbangan yang rasional agar tercapainya tujuan bersama. Hal penting dalam teori stewardship adalah manajer menyelaraskan tujuannya sesuai dengan tujuan Principal namun tidak berarti steward tidak memiliki kebutuhan (Raharjo, 2007).

\section{Keefektifan Pengendalian Internal Berdampak terhadap Kecenderungan Kecurangan Akuntansi}

Prawira (2014) menunjukkan keefektifan pengendalian internal dapat mencegah dan mengurangitindakan kecenderungan kecurangan akuntansi didalam manajemen yang berarti semakin efektif pengendalian internal dalam organisasi maka semakin rendah tindakan kecurangan akuntansi. Kepatuhan pengendalian internal memberikan ketentuan mengenai prosedur untuk mendapatkan dan menggunakan kemajuan kerja, pembelian peralatan dan persediaan permintaan resmi, penggunaan fasilitas yang dimiliki dan akuntabilitas. Ketentuan ini berlaku untuk pihak-pihak terkait dan dipantau oleh pejabat yang berwenang. Ketidaktepatan ketentuan ini mengarah pada proses permintaan pembayaran berikutnya pada bulan depan, dan secara berkala itu juga mengevaluasi oleh BPK. Upaya ini berguna dalam menekan kecenderungan kecurangan. Dengan demikian dapat dikatakan bahwa semakin efektif pengendalian internal maka kecenderungan kecurangan akuntansi dapat diminimalisir. Berdasarkan uraian tersebut, maka hipotesis pertama yang dapat diajukanialah: 
H1: Keefektifan pengendalian internal berdampak terhadap kecenderungan kecurangan akuntansi.

\section{Ketaatan Aturan Akuntansi Berdampak terhadap Kecenderungan Kecurangan Akuntansi}

Shintadevi (2015) menyebutkan bahwa kegagalan penyusunan laporan keuangan yang disebabkan karena ketidaktaatan dapat dideteksi melalui pernyataan standar yang jelas. Ketaatan aturan akuntansi merupakan suatu kewajiban dalam organisasi untuk mematuhi segala ketentuan atau aturan akuntansi dalam melaksanakan pengelolaaan keuangan dan pembuatan laporan keuangan agar terciptanya transparansi dan akuntanbilitas pengelolaan keuangan dan laporan keuangan yang dihasilkan efektif, handal, serta akurat informasinya. Adanya aturan akuntansi tersebut menghindari tindakan yang menyimpang yang dapat merugikan organisasi. Suatu instansi atau lembaga melakukan tindakan kecurangan karena mereka tidak berpedoman pada aturan akuntansi yang berlaku. Jika lembaga atau instansi taat terhadap aturan akuntansi yang berlaku kecenderungan kecurangan akuntansi dapat berkurang. Berdasarkan uraian tersebut, maka hipotesis kedua yang dapat diajukan ialah :

H2: Ketaatan aturan akuntansi berdampak terhadap kecenderungan kecurangan akuntansi.

\section{Kesesuaian kompensasi berdampak terhadap kecenderungan kecurangan akuntansi.}

Kesesuaian kompensasi adalah keseluruhan balas jasa yang diterima oleh pegawai sebagai akibat dari pelaksanaan di organisasi dalam bentuk uang atau lainnya, yang dapat berupa gaji, upah, bonus, insentif dll (Hariandja, 2005).Jika para karyawan tidak puas atas kompensasi yang diterimanya maka akan berdampak terhadap organisasi. Artinya jika ketidakpuasan tersebut tidak diselesaikan dengan baik, maka setiap karyawan menyatakan keinginan untuk memperoleh kompensasi yang sesuai. Kompensasi yang sesuai merupakan rangkaian dengan berbagai segi kehidupan, seperti prestasi kerja, keluhan, terjadinya kecelakaan dalam melaksanakan tugas, dan adanya keinginan untuk pindah kerja (Sofyandi, 2008). Penelitian milik Meilany (2013) mengenai kecenderungan kecurangan akuntansi juga menyatakan bahwa` dengan adanya kesesuaian kompensasi maka pegawai atau karyawan dapat menyelesaikan pekerjaannya dengan baik. Hasil penelitian ini juga didukung oleh penelitian Thoyibatun (2009) yang mengatakan bahwa perbaikan perencanaan struktur insentif akan mempengaruhi cara manajerberperilaku dalam mencapai kinerja. Pada kondisi tertentu memiliki arah positif dimana pemberian kompensasi yang sesuai kepada karyawan akan mengurangi kecenderungan kecurangan akuntansi yang terjadi di perusahaan. Dengan demikian pemberian kompensasi yang sesuai dan layak akan meminimalisir terjadinya kecenderungan kecurangan akuntansi. Berdasarkan uraian tersebut, maka hipotesis ketiga yang dapat diajukan ialah :

H3 : Kesesuaian kompensasi berdampak terhadap kecenderungan kecurangan akuntansi

\section{Asimetri Informasi Berdampak terhadap Kecenderungan Kecurangan Akuntansi}

Asimetri informasi yaitu ketidakseimbangan antara pemilik (principal) dan pengelola (agent) (Fitri, 2016). Jika ketidakseimbangan informasi terjadi dalam pemerintah daerah yaitu antara pemimpin atau pegawai dengan masyarakat, maka akan memberikan peluang bagi pengelola dana untuk melakukan tindak penyelewengan dana dan manipulasi data. Penelitian Ariani, 
Musmini, Herawati (2014) menunjukkan bahwa asimetri informasi mempunyai arah pengaruh positif dan signifikan terhadap kecenderungan kecurangan akuntansi, artinya apabila asimetri informasi semakin meningkat, bisa meningkatkan kecenderungan kecurangan akuntansi.

H4 : Asimetri Informasi berdampak terhadap kecenderungan kecurangan akuntansi.

\section{METODE PENELITIAN}

\section{Populasi dan Sampel Penelitian}

Populasi dalam penelitian ini adalah Satuan Kerja Perangkat Daerah (SKPD) Kota Pekanbaru yang berjumlah 43 SKPD yang terdiri dari dinas, kantor dan badan di Kota Pekanbaru, yaitu terdapat 2 sekretariat, 1 inspektorat, 17 dinas, 1 satpol PP, 1 kantor, 10 badan dan 11 Kecamatan. Dengan sampel penelitian berjumlah 108 responden. Metode pemilihan sampel yang digunakan adalah purposive sampling, yaitu pengambilan sampel yang terbatas pada jenis orang tertentu yang dapat memberikan informasi yang diiinginkan, entah karena mereka adalah satu-satunya memilikinya, atau memenuhi beberapa kriteria yang ditentukan oleh peneliti (Sekaran, 2009).Sampel penelitian ini merupakan pegawai pemerintah yang berada di bagian keuangan yang terdiri dari kabag/kasubag keuangan, bendahara dan staf bagian keuangan dengan total 108. Alasan atau pertimbangannya yaitu responden dalam penelitian ini termasuk sebagai pegawai yang ikut serta menyusun, menggunakan, dan melaporkan realisasi anggaran atau sebagai pelaksana anggaran pemerintah daerah.

\section{Definisi dan Operasional Variabel}

Dalam penelitian ini variabel independen (X1) yang digunakan adalah efektifitas pengendalian internal, yang didefinisikan sebagai suatu proses yang dipengaruhi oleh dewan direksi, entitas, manajemen, dan personel lainnya yang dirancang untuk memberikan kepastian yang beralasan terkait dengan pencapaian sasaran kategori, seperti efektifitas dan efisiensi operasi, keandalan pelaporan keuangan, ketaatan terhadap hukum, dan peraturan yang berlaku (Rama \& Jones, 2008:132).Instrumen yang digunakan untuk mengukur Keefektifan Pengendalian Internal terdiri dari dua puluh tujuh item pernyataan berdasarkan komponen pengendalian internal menurut Arens (2009)Pengukuran variabel efektifitas pengendalian internal dilakukan melalui lima indikator. Lima indikator tersebut diukur dengan skala likert 1 sampai 5.

Variabel Independen Selanjutnya (X2) Ketaatan Aturan Akuntansi adalah suatu kewajiban dalam organisasi untuk mematuhi segala ketentuan atau aturan akuntansi dalam melaksanakan pengelolaan keuangan dan pembuatan laporan keuangan agar tercipta transparansi dan akuntabilitas pengelolaan keuangan dan laporan keuangan yang dihasilkan efektif, handal serta akurat informasinya (Shintadevi, 2015).Instrumen yang digunakan untuk mengukur Ketaatan Aturan Akuntansi terdiri dari tiga belas item pernyataan mengacu pada penelitian Thoyibatun (2009).Pengukuran variabel ketaatan aturan akuntansi dilakukan melalui lima indikator. Lima indikator tersebut diukur dengan skala likert 1 sampai 5

Variabel independen yang ketiga (X3) dalam penelitian ini adalah kesesuaian kompensasi, yang didefinisikan sebagai keseluruhan balas jasa yang diterima oleh pegawai sebagai akibat dari pelaksanaan di organisasi dalam bentuk uang atau lainnya, yang dapat berupa gaji, upah, bonus, insentif, dan tunjangan lainnya (Hariandja, 2002).Instrumen yang digunakan untuk mengukur Kesesuaian Kompensasi terdiri delapan belas item pernyataan 
berdasarkan Komponen Kompensasi menurut Veitzhal Rivai (2011). Pengukuran variabel kesesuaian kompensasi dilakukan melalui enam indikator. Enam indikator tersebut diukur dengan skala likert 1 sampai 5.

Variabel independen yang keempat (X4) dalam penelitian ini adalah asimetri informasi, yang didefinisikan oleh Kurniawan (2012) dalam Bartenputra (2016) adalah sebagai suatu kondisi dimana terjadi ketidakseimbangan yang dimiliki oleh agen dan principal yang disebabkan karena distribusi informasi yang tidak sama antara kedua belah pihak.Instrumen yang digunakan untuk mengukur asimetri informasi diukur dengan tujuh item pernyataan yang dikembangkan oleh peneliti dari Dunk (1993) dalam Wilopo (2006). Pengukuran variabel asimetri informasi dilakukan melalui enam indikator. Enam indikator tersebut diukur dengan skala likert 1 sampai 5.

\section{HASIL DAN PEMBAHASAN}

Penelitian ini menggunakan teknik pengumpulan data dengan kuesioner yang disebarkan kepada sampel penelitian yang bersangkutan. Teknik angket (kuesioner) merupakan suatu pengumpulan data dengan memberikan atau menyebarkan daftar pertanyaan/pernyataan kepada responden dengan harapan memberikan respons atas daftar pertanyaan tersebut (Husein Umar, 2011). Kuesioner yang disebarkan berupa daftar pertanyaan yang berkaitan dengan obyek yang diteliti, kuesioner diberikan disertai dengan surat permohonan izin dan penjelasan mengenai tujuan dari penelitian yang dilakukan tersebut. Selain itu, dalam penyebaran kuesioner juga disertakan petunjuk pengisian yang jelas agar memudahkan responden dalam memberikan jawabannya secara lengkap.

Tabel 1.

Hasil Uji Statistik Deskriptif

\begin{tabular}{lcrr}
\hline & N & \multicolumn{1}{l}{ Mean } & \multicolumn{1}{l}{ Std. Deviation } \\
\hline Pengendalian Internal & 108 & 37.98 & 5.65 \\
\hline Ketaatan Aturan Akuntansi & 108 & 39.63 & 5.60 \\
\hline Kesesuaian Kompensasi & 108 & 38.30 & 4.45 \\
\hline Asimetri Informasi & 108 & 22.11 & 4.48 \\
\hline Kecenderungan Kecurangan Akuntansi & 108 & 31.62 & 7.99 \\
\hline Valid N (listwise) & 108 & & \\
\hline
\end{tabular}

(Sumber : Hasil Pengelolaan SPSS 20, 2018)

\section{Goodness of Fit Model}

Koefisien determinasi $\left(\mathrm{R}^{2}\right)$ bertujuan untuk melihat atau mengukur seberapa jauh kemampuan model dalam menerangkan variasi dependen. Nilai pengukuran koefisien determinasi dapat dilihat pada besarnya Adjusted R Square yang diambil dari model summary (Ghozali, 2013 :97). 
Adhilla Aninta Putri \& Swarmilah Hariani

Internal control, compliance, compensation....

Tabel 2.

Hasil Koefisien Determinasi

Model Summaryb

\begin{tabular}{lcrrrr}
\hline & & \multicolumn{2}{c}{ Adjusted R } & \multicolumn{2}{c}{ Std. Error of the } \\
Model & $\mathrm{R}$ & R Square & Square & Estimate & Durbin-Watson \\
\hline 1 & $.980^{\mathrm{a}}$ & .637 & .611 & 6.63640 & 1.870 \\
\hline
\end{tabular}

Sumber : Hasil Pengolahan SPSS 20,

Berdasarkan Tabel 2 di atas menunjukkan bahwa besarnya Adjusted R Square adalah 0,611. Hal ini mengindikasikan bahwa kontribusi variabel pengendalian internal, ketaatan aturan akuntansi, kesesuaian kompensasi dan Asimetri informasi adalah 61,1\% sedangkan 38,9\% ditentukan oleh factor lain di luar model yang tidak terdeteksi dalam penelitian ini.

Uji Statistik F dasarnya menunjukan variabel independen atau bebas yang dimasukan dalam model mempunyai pengaruh secara bersama - sama terhadap variabel dependen/ terikat. (Ghozali, 2013: 98)

Tabel 3.

Hasil Uji Signifikansi Simultan (Uji F)

ANOVAb

\begin{tabular}{llrrrrr}
\hline \multicolumn{1}{l}{ Model } & Sum of Squares & df & Mean Square & F & \multicolumn{1}{c}{ Sig. } \\
\hline \multirow{2}{*}{1} & Regression & 2305.136 & 4 & 576.284 & 13.085 & $.000^{\mathrm{a}}$ \\
\cline { 2 - 7 } & Residual & 4536.299 & 103 & 44.042 & & \\
\cline { 2 - 8 } & Total & 6841.435 & 107 & & & \\
\hline
\end{tabular}

Sumber : Hasil Pengolahan SPSS

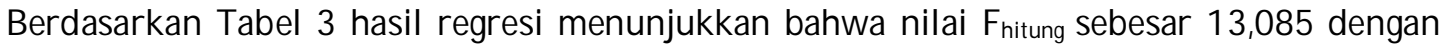
tingkat signifikan sebesar 0,000 . Dengan demikian dapat dikatakan bahwa $F_{\text {hitung }}$ lebih besar dari $\mathrm{F}_{\text {tabel }}$ yaitu 13,085 > 2,46 atau nilai signifikan 0,000<0,05. Hal tersebut menandakan model regresi dapat memprediksi bahwa pengendalian internal, ketaatan aturan akuntansi, kesesuaian kompensasi dan Asimetri informasi

Tabel 4.

Hasil Uji Signifikansi Parameter Individual (Uji t)

\begin{tabular}{llrrrr}
\hline & B & Std. Error & t-value & Sig \\
\hline 1 & 3.669 & 6.435 & .570 & .570 \\
\cline { 2 - 6 } & Pengendalian Internal & .277 & .140 & 1.986 & .040 \\
\cline { 2 - 6 } & Ketaatan Aturan Akuntansi & .290 & .129 & 2.250 & .027 \\
\hline Kesesuaian Kompensasi & .502 & .178 & 3.903 & .000 \\
\cline { 2 - 6 } & Asimetri Informasi & .440 & .165 & 2.662 & .009 \\
\hline
\end{tabular}

Sumber : Hasil Pengolahan SPSS 2018)

Tabel 4 menunjukan hasil uji hipotesis, Untuk variabel pengendalian internal nilai t hitung adalah 1,986 (sig < 0.05). Dengan demikian dapat dikatakan bahwa hipotesis ini terbukti signifikan pada level 5 persen, sehingga H1 diterima. Pengujian hipotesis menunjukkan nilai t value 2.25 (sig < 0.05) juga terbukti sehingga ketaatan aturan akuntasi secara signifikan 
mempengaruhi kecenderungan kecurangan akuntansi. Kompensasi dan asimetri informasi juga terbukti signifikan ( $\mathrm{sig}<0.05)$. Dapat dinyatakan bahwa seluruh hipotesis diterima.

\section{Pembahasan}

Pegendalian internal berpengaruh negatif signifikan terhadap kecenderungan kecurangan akuntansi. Artinya, semakin efektif pengendalian internal maka kecenderungan kecurangan akuntansi dapat diminimalisir. Prawira (2014) menunjukkan keefektifan pengendalian internal dapat mencegah dan mengurangi tindakan kecenderungan kecurangan akuntansi didalam manajemen yang berarti semakin efektif pengendalian internal dalam organisasi maka semakin rendah tindakan kecurangan akuntansi. Kepatuhan pengendalian internal memberikan ketentuan mengenai prosedur untuk mendapatkan dan menggunakan kemajuan kerja, pembelian peralatan dan persediaan permintaan resmi, penggunaan fasilitas yang dimiliki dan akuntabilitas. Ketentuan ini berlaku untuk pihak-pihak terkait dan dipantau oleh pejabat yang berwenang. Ketidaktepatan ketentuan ini mengarah pada proses permintaan pembayaran berikutnya pada bulan depan, dan secara berkala itu juga mengevaluasi oleh BPK. Upaya ini berguna dalam menekan kecenderungan kecurangan.

Ketaatan aturan akuntansi berpengaruh negatif signifikan terhadap kecenderungan kecurangan akuntansi, artinya semakin taat terhadap aturan akuntansi maka kecenderungan kecurangan akuntansi dapat diminimalisir. Shintadevi (2015) menyebutkan bahwa kegagalan penyusunan laporan keuangan yang disebabkan karena ketidaktaatan dapat dideteksi melalui pernyataan standar yang jelas. Ketaatan aturan akuntansi merupakan suatu kewajiban dalam organisasi untuk mematuhi segala ketentuan atau aturan akuntansi dalam melaksanakan pengelolaaan keuangan dan pembuatan laporan keuangan agar terciptanya transparansi dan akuntanbilitas pengelolaan keuangan dan laporan keuangan yang dihasilkan efektif, handal, serta akurat informasinya. Adanya aturan akuntansi tersebut menghindari tindakan yang menyimpang yang dapat merugikan organisasi. Suatu instansi atau lembaga melakukan tindakan kecurangan karena mereka tidak berpedoman pada aturan akuntansi yang berlaku. Jika lembaga atau instansi taat terhadap aturan akuntansi yang berlaku kecenderungan kecurangan akuntansi dapat berkurang.

Kesesuaian kompensasi terbukti berpengaruh negatif signifikan terhadap kecenderungan kecurangan akuntansi, sehingga kompensasi yang sesuai dan layak akan meminimalisis terjadinya kecenderungan kecurangan akuntansi. Didalam beberapa penelitian terdahulu, yaitu Monica (2012); Wilopo (2006); Thoyibatun (2009) dan Meliany (2013) menjelaskan bahwa kesesuaian kompensasi dalam suatu perusahaan dilihat dari kompensasi keuangan, pengakuan perusahaan atas keberhasilan dalam melaksanakan pekerjaan, promosi, penyelesaian tugas, pencapaian sasaran, dan pengembangan pribadi karyawan perusahaan itu.Menurut penelitian Dewi (2017) menyatakan bahwa kompensasi berpengaruh negative signifikan terhadap kecenderungan kecurangan akuntansi. Semakin tinggi kesesuaian kompensasi maka kecenderungan kecurangan akuntansi juga akan semakin turun. Selain itu, penelitian milik Meilany (2013) mengenai kecenderungan kecurangan akuntansi juga menyatakan bahwa' dengan adanya kesesuaian kompensasi maka pegawai atau karyawan dapat menyelesaikan pekerjaannya dengan baik.

Asimetri Informasi (X4) berpengaruh positif signifikan terhadap kecenderungan kecurangan akuntansi,sehingga H4dalampenelitianiniditerima. Artinya,apabila asimetri informasi semakin meningkat, bisa meminimalisir kecenderungan kecurangan akuntansi. Penelitian Ariani, Musmini, Herawati (2014) menunjukkan bahwa asimetri informasi 
mempunyai arah pengaruh positif dan signifikan terhadap kecenderungan kecurangan akuntansi, artinya apabila asimetri informasi semakin meningkat, bisa meningkatkan kecenderungan kecurangan akuntansi.

\section{KESIMPULAN}

Penelitian ini bertujuan untuk mengidentifikasi determinan kecenderungan kecurangan akuntansi. Berdasarkan hasil studi diketahui bahwa efektivitas pengendalian internal, ketaatan aturan akuntansi, dan komitmen organisasi dapat digunakan sebagai faktor penyebab kecenderungan kecurangan (fraud) akuntansi. Pengendalian internal berpengaruh negatif signifikanterhadapkecenderungan kecurangan akuntansi padaSKPD KotaPekanbaru. Semakin efektif pengendalian internal maka kecenderungan kecurangan akuntansi dapat diminimalisir. Keefektifan pengendalian internal dapat mencegah dan mengurangi tindakan kecenderungan kecurangan akuntansi didalam manajemen yang berarti semakin efektif pengendalian internal dalam organisasi maka semakin rendah tindakan kecurangan akuntansi, hal tersebut telah diterapkan oleh SKPD Kota Pekanbaru untuk semakin menimalisir kecenderungan kecurangan akuntansi dengan meningkatkan pengendalian internal pada SKPD yang ada di Kota Pekanbaru.

Ketaatan aturan akuntansi berpengaruh negatif signifikan terhadapkinerja keuangan pemerintah daerahpadaSKPD Kota Pekanbaru.Halinimenunjukanbahwa semakin taat terhadap aturan akuntansi maka kecenderungan kecurangan akuntansi dapat diminimalisir. Kegagalanpenyusunan laporan keuangan yang disebabkan karena ketidaktaatan dapat dideteksi melalui penyertaan standar yang jelas. Ketaatan aturan akuntansi merupakan suatu kewajiban dalam organisasi untuk mematuhi segala ketentuan aturan akuntansi dalam melaksanakan pengelolaan keuangan dan pembuatan laporan keuangan agar terciptanya transparasi dan akuntabilitas pengelolaan keuangan dan laporan keuangan yang efektif pada SKPD Kota Pekanbaru.

Kesesuaian kompensasi berpengaruhnegatif signifikanterhadapkecenderungan kecurangan akuntansi SKPD Kota Pekanbaru. Halinimenunjukan bahwa Pemberian Kompensasi yang sesuai dan layak akan meminimalisis terjadinya kecenderungan kecurangan akuntansi. Kompensasi keuangan, pengakuan perusahaan atas keberhasilan dalam melaksanakan pekerjaan, promosi, penyelesaian tugas, pencapaian sasaran dan pengembangan pribadi karyawan. Pada SKPD Kota Pekanbaru kesesuaian kompensasi telah dipertimbangkan dengan baik agar tidak terjadinya kecenderungan kecurangan akuntansi Asimetri Informasi berpengaruh positif signifikan terhadap Kecenderungan kecurangan akuntansi.Halinimenunjukanapabila asimetri informasi semakin meningkat, bias meminimalisir kecenderungan kecurangan akuntansi. Pada SKPD Kota Pekanbaru asimetri informasi dijalankan dengan baik agar dapat meminimalisir kecenderungan kecurangan akuntansi.

\section{Keterbatasan}

Penelitian memiliki keterbatasan terutama pada pengumpulan data dari kuesioner selfassessment yang kemungkinan dapat bias kepentingan. Studi lanjutan perlu mempertimbangkan metode pengambilan data yang memisahkan antara determinan dan outcome, artinya kecenderungan kecurangan akuntansinya dapat mengambil data eksternal. 


\section{REFERENSI}

Adelin, V. (2013). Pengaruh Pengendalian Internal, Ketaatan Aturan Akuntansi, Dan Perilaku Tidak Etis Terhadap Kecenderungan Kecurangan Akuntansi (Studi Empiris pada BUMN di Kota Padang). Jurnal Akuntansi, 1(3).

Ahriati, D., Basuki, P., \& Widiastuty, E. (2016). Analisis Pengaruh Sistem Pengendalian Internal, Asimetri Informasi, Perilaku Tidak Etis dan Kesesuaian Kompensasi Terhadap Kecenderungan Kecurangan Akuntasi Pada Pemerintah Daerah Kabupaten Lombok Timus. Jurnal InFestasi, 11 (1), 41-55.

Arens A. Alvin. Ellder J. Ronald \& Beasley Mark S. (2008). Auditing dan Jasa Assurance Pendekatan Terintegrasi. Jakarta: Erlangga.

Ariani, K. S., Musmini, L. S., Herawati, N. T., \& AK, S. (2014). Analisis Pengaruh Moralitas Individu, Asimetrii Informasi dan Keefektifan Sistem Pengendalian Internal Terhadap Kecenderungan Kecurangan Akuntansi di PDAM Kabupaten Bangli. JIMAT (Jurnal Ilmiah Mahasiswa Akuntansi) Undiksha, 2(1).

Azmi, N. (2013). Pengaruh Ketaatan Aturan Akuntansi, Kesesuaian Kompensasi dan Asimetri Informasi Terhadap Kecenderungan Kecurangan Akuntansi (Studi Pada BUMN di Kota Padang). Jurnal Akuntansi, 5(2).

Dewi, C. K. R., Surya, R. A. S., \& Hasan, M. A. (2016). Pengaruh Pengendalian Internal, Kesesuaian Kompensasi, Ketaatan Aturan Akuntansi, Dan Perilaku Tidak Etis Terhadap Kecenderungan Kecurangan Akuntansi (Studi Empiris Pada Skpd Kabupaten Bengkalis). Jurnal Online Mahasiswa (JOM) Bidang Ilmu Ekonomi, 4(1), 1443-1457.

Hall, James. A. (2009). Sistem Informasi Akuntansi, Penerjemah Amir Abadi Yusuf. Jakarta: PT Salemba Empat.

Husein Umar. (2011). Metode Penelitian Untuk Skripsi dan Tesis Bisnis. Jakarta: PT Rajagrafindo Persada.

Ikatan Akuntan Indonesia. (2009). Standar Akuntansi Keuangan. Jakarta: Ikatan Akuntan Indonesia.

Mulyadi. (2001). Sistem Akutansi. Jakarta: Salemba Empat.

News Detik. (2015). Gubernur Riau Nonaktif Annas Maamun didakwa Tiga Kasus Suap Rp. 55 M. Diakses dari https://news.detik.com/berita/2829877/gubernur-riau-nonaktifannas-maamun-didakwa-tiga-kasus-suap-rp-55-m

Pekanbaru Tribun News. (2017). Riau Masih Masuk 5 Besar Provinsi dengan Kasus Korupsi Terbanyak. Diakses dari http:// pekanbaru.tribunnews.com/2017/12/08/riau-masihmasuk-5-besar-provinsi-dengan-kasus-korupsi-terbanyak

Rahmaidha, R., \& Sukirno, S. (2017). Pengaruh Keefektifan Pengendalian Internal, Ketaatan Aturan Akuntansi, dan Kepuasan Kerja Terhadap Kecurangan Akuntansi. Jurnaal Profita: Kajian Ilmu Akuntansi, 5(4).

Ramadhany, I., Indrawati, N., \& Al Azhar, L. (2016). Pengaruh Sistem Pengendalian Intern, Asimetri Informasi, Kesesuaian Kompensasi Dan Implementasi Good Corporate Governance Terhadap Kecenderungan Kecurangan Akuntansi (Studi Empiris Pada Rumah Sakit Swasta Yang Ada Di Pekanbaru). Jurnal Online Mahasiswa (JOM) Bidang Ilmu Ekonomi, 4(1), 1253-1267. 
Republik Indonesia. (2005). Peraturan Pemerintah No. 24 Tahun 2005 tentang Standar Keuangan Akuntansi. Lembaran Negara RI Tahun 2005. Sekretariat Negara. Jakarta.

Shintadevi, P. F. (2015). Pengaruh Keefektifan Pengendalian Internal, Ketaatan Aturan Akuntansi dan Kesesuaian Kompensasi terhadap Kecenderungan Kecurangan Akuntansi dengan Perilaku Tidak Etis sebagai Variabel Intervening. Nominal, Barometer Riset Akuntansi dan Manajemen, 4(2).

Sindo News. (2017). Diduga Korupsi Uang Bencana Dua Pegawai Pemkab Pelalawan Tersangka. Diakses dari https:// daerah.sindonews.com/read/1236826/174/ didugakorupsi-uang-bencana-dua-pegawai-pemkab-pelalawan-tersangka-1504602597

Sindo News. (2017). Terbukti Korupsi Mendagri Berhentikan Bupati Rohul. Diakses dari https:/ / daerah.sindonews.com/read/1257960/174/ terbukti-korupsi-mendagriberhentikan-bupati-rohul-1510821955

Sugiyono. (2014). Metode Penelitian Pendidikan. Bandung: Alfabeta.

Thoyibatun, Siti. 2009. Faktor-Faktor yang Berpengaruh Terhadap Perilaku Tidak Etis dan Kecenderungan Kecurangan Akuntansi Serta Akibatnya Terhadap Kinerja Organisasi. Jurnal Ekonomi dan Keuangan.

Veithzal, Rivai. (2014). ManajemenSumber Daya Manusia Untuk Perusahaan. Jakarta: PT Raja Grafindo Persada.

Widiutami, N. P. S., Sulindawati, N. L. G. E., \& Atmadja, A. T. (2017). Pengaruh Efektivitas Pengendalian Internal, Ketaatan Aturan Akuntansi, dan Komitmen Organisasi Terhadap Kecenderungan Kecurangan (Fraud) Akuntansi (Studi Empiris Pada Lembaga Perkreditan Desa Di Kabupaten Buleleng). JIMAT (Jurnal Ilmiah Mahasiswa Akuntansi) Undiksha, 7(1). 


\section{DECLARATIONS}

\section{Funding}

The authors received no financial support for the research and publication of this article.

\section{Conflicts of interest/ Competing interests:}

The authors have no conflicts of interest to declare that are relevant to the content of this article.

Data, Materials and/ or Code Availability:

Data sharing is not applicable to this article as no new data were created or analyzed in this study.

\section{Notes on Contributor}

Adhilla Aninta Putri dan Swarmilah Hariani adalah mahasiswa dan Dosen di Fakultas Ekonomi dan Bisnis, Universitas Mercu Buana Jakarta, Indonesia

\section{How to cite this Article}

Putri, A., \& Hariani, S. (2021). Determinan Kecenderungan Kecurangan Akuntansi. AKURASI: Jurnal Riset Akuntansi Dan Keuangan, 3(1), 17 - 28 